\title{
Komunikasi Massa pada Kerja Kuratorial Festival Film Sineas Mahasiswa 2020 di Bandung
}

\author{
Nala Nandana Undiana ${ }^{1}$, Irwan Sarbeni' ${ }^{2}$, Arsya Ardiansyah ${ }^{3}$, Amany Putri Razan ${ }^{4}$ \\ ${ }^{1234}$ Universitas Pendidikan Indonesia \\ Email: nalanandana@upi.edu
}

\begin{abstract}
Film festivals are now becoming increasingly popular activities and are also one of the multidisciplinary activities that hold many practitioners' ideas in them. This study looks at curatorial work practices carried out by curators in organizing film festivals. In this research the method used is descriptive analysis which focuses on the mass communication patterns carried out by the curator when delivering messages in the curatorial work process. The data used is a collection of observations, interviews and other supporting data from curators involved in the 2020 Student Film Film Festival. This study describes the tendency of curatorial work practices in organizing a film festival, especially in the process of designing program programs and selecting films conducted during the festival takes place. In this study, it can be argued that the curatorial process does not merely discuss the technical matters of the implementation of a film festival activity, but furthermore, curatorial work practices become a media for disseminating information to the public and also an important part in the process of forming discourse and issues that will be a tendency the form of work of festival participants in general.
\end{abstract}

Keywords: film festival, curatorial, mass communication

\begin{abstract}
Abstrak: Festival film saat ini menjadi kegiatan yang semakin popular dan juga menjadi salah satu kegiatan multidisiplin yang menampung banyak ide praktisi di dalamnya. Penelitian ini melihat praktik kerja kuratorial yang dilakukan oleh kurator dalam penyelenggraan festival film. Dalam penelitian ini metode yang digunakan adalah analisis deskriptif yang bertitik berat pada pola komunikasi massa yang dilakukan oleh kurator saat menyampaikan pesan dalam proses kerja kuratorialnya. Data yang digunakan adalah kumpulan hasil pengamatan, wawancara dan data pendukung lain dari para kurator yang terlibat dalam Festival Film Sineas Mahasiswa 2020. Penelitian ini menjabarkan kecenderungan praktik kerja kuratorial pada penyelenggaraan sebuah festival film, terutama pada proses perancangan program kegiatan dan pemilihan film yang dilakukan selama festival berlangsung. Dalam penelitian ini, dapat dikemukakan bahwa proses kuratorial tidak sematamata membahas perihal teknis pelaksanaan sebuah kegiatan festival film, namun lebih jauh, praktik kerja kuratorial menjadi media penyebar informasi pada khalayak publik dan juga bagian penting dalam proses pembentuk wacana dan isu yang akan menjadi kecenderungan bentuk karya para peserta festival pada umumnya.
\end{abstract}

Kata kunci: festival film, kuratorial, komunikasi massa

\section{Pendahuluan}

Festival film saat ini menjadi kegiatan yang semakin popular dan juga menjadi salah satu kegiatan multidisiplin yang menampung banyak ide praktisi di dalamnya. Bentuk keterlibatan secara langsung setiap praktisi di dalamnya memberikan banyak kemungkinan berbagai bahan diskursus yang dapat diolah dalam setiap penyelenggaraannya. Salah satu kegiatan festival film ditingkat mahasiswa yang masih bertahan hingga saat ini adalah 
Festival Film Dokumenter (FFD) yang diselenggarakan pertama kali pada tahun 2002 oleh Gelanggang Audio Visual Universitas Gadjah Mada (GLAV UGM) dan Tembi Rumah Budaya. Festival Film Dokumenter tercetus dari kegelisahan atas keberadaan media, khususnya TV Nasional yang memberikan tontotan yang tidak mendidik, sehingga muncul gagasan untuk mengadakan lomba film dokumenter. Lomba film dokumenter ini ditujukan untuk mendorong minat membuat film khususnya di kalangan mahasiswa di Yogyakarta, agar aktivitas membuat film ini terbawa saat kembali ke daerah masing-masing.

Dalam praktiknya, festival film juga kerap kali menampilkan berbagai hal menarik dalam produksi sinema, hal ini pula yang membuat festival film menjadi arus balik bagi arus utama (mainstream) dalam pergerakan sinema global (Iordanova, 2009). Bahasan ini membuat festival film memiliki fungsi sebagai ruang yang mengajak penonton untuk berpartisipasi di dalamnya, dengan kata lain seperti pengamatan budaya dunia yang lebih luas dan juga sebagai ruang yang menyediakan berbagai bentuk aspek penting dari pertunjukan dalam budaya film secara global (Czach, 2004; Van Hemert, 2013).

Festival film menjadi fenomen aktivitas yang beragam dan kompleks, selain itu festival film juga menjadi area bertumbuhnya ketertarikan setiap praktisi yang terlibat dalam melakukan penelitian atau pengamatan pada sebuah subjek dari berbagai sudut pandang. Dalam praktiknya, pertumbuhan berbagai bentuk festival film menjadi penting untuk diteliti karena keterkaitannya dengan berbagai bentuk praktik seperti pemutaran film, distribusi karya film, pertumbuhan budaya, kemasyarakatan serta pertumbuhan ekonomi (Fischer, Sju, and Bond, 2009; Rüling and Strandgaard Pedersen, 2010).

Berbagai peristiwa dalam festival film yang dirangkum dalam sebuah program besar merupakan bentuk eksplorasi yang penting untuk ditampilkan. Dalam hal ini, kerja kuratorial dari seorang kurator menjadi faktor penting yang menentukan jalannya peristiwa dalam program festival film. Kurator merupakan seorang ahli dalam praktik pengkajian film yang memiliki keahlian untuk memediasi antara koleksi film dan penonton dengan melakukan seleksi secara komprehensif pada program yang berjalan pada sebuah festival film (Cherchi Usai et al., 2008; Genkova, 2010). Proses kurasi dalam festival film merupakan praktik pengumpulan dan akuisisi dari koleksi film oleh seseorang atau satu kelompok (lebih dari satu orang). Praktik kurasi juga melibatkan berbagai bentuk pemeliharaan, gagasan pembuatan katalog hingga identifikasi koleksi film secara mendalam (Klippel, 2008). Sehingga proses penelitian pada festival film di Indonesia dapat memungkinkan peneliti untuk mengungkap dari peran kurator dan praktik kerja kuratorial dalam penyelenggaraannya. Untuk mengeksplorasi dan menyelidiki secara spesifik cara pandang penonton pada festival film, penelitian ini menjabarkan cara pandang seorang kurator dalam menciptakan suasana bagi program yang digulirkan dalam festival film. Apresiasi dari penonton, para pemangku kepentingan (stakeholder) dan sineas dalam melakukan eksplorasi pada wujud peristiwa di lapangan saat festival film berlangsung.

Untuk membuat sebuah kegiatan yang akan terus diingat, peran pembuat program dalam festival film tidak akan pernah lepas dari manajemen kegiatan itu sendiri, hal ini melibatkan penggunaan akal sehat, pengalaman dan imajinasi (Manners, Saayman, and Kruger, 2015). Walaupun demikian, peneliti menyadari jika peran penting dalam sebuah festival film juga ada dalam sudut pandang penonton. Sebuah penelitian telah dilakukan untuk 
mengidentifikasi faktor-faktor pembentukan pengalaman yang dapat berkesan dari sudut pandang penonton. Oleh karena itu, secara definitif penelitian ini melihat dari sudut pandang peran seorang kurator dalam melakukan eksplorasi program festival film. Hal ini akan membantu memberikan pemahaman tentang praktik kuratorial secara profesional. Selain itu pemahaman terkait representasi penonton yang datang sehingga memperoleh pengalaman baru saat terlibat dalam berbagai program juga menjadi indikator yang penting dalam pelaksanaan sebuah festival film (Rastegar, 2012).

Dari perspektif multi-disiplin, sebuah agenda festival film ditujukan sebagai indikator dari tren perkembangan film di suatu wilayah (kota/ negara). Selain itu, festival film juga dapat ditujukan sebagai media yang digunakan untuk mempromosikan berbagai bentuk tradisi sinematik dan identitas budaya. Banyak praktisi film ikut serta atau bahkan mengadakan sebuah kegiatan festival film untuk menampilkan keragaman budaya, baik yang bersifat konvensional maupun kontemporer pada khalayak publik. Dalam hal ini publik yang dimaksud dapat dalam cakupan satu negara (nasional) atau di lingkup internasional. Hal ini pula yang memungkinkan para sineas yang terlibat didalamnya memperoleh pengakuan, baik dalam segi keunikan budaya yang ditampilkan pada karyanya, maupun hal-hal yang menarik minat pemangku kepentingan, seperti industri film dan pelaku bisnis film (Valck, 2019).

Kegiatan festival film pada dasarnya dapat membantu proses validasi industri film, hal ini dilakukan melalui kontribusi sineas yang terlibat di dalamnya terhadap perkembangan budaya film secara global. Di luar apresiasi sineas, festival film adalah forum yang dapat mendukung perkembangan budaya film di suatu negara, praktik ini dapat juga dikatakan sebagai bentuk penyebaran informasi secara massal yang diwakili oleh karya para sineas. Sebagai bentuk penyebaran informasi secara massal, teks-teks dalam bentuk visual (film) yang ditampilkan oleh program festival film dapat membentuk sebuah kerja kolaborasi antar sineas yang dibentuk melalui kumpulan visual dalam kerangka kerja secara global.

Bentuk komunikasi massa pada festival film adalah proses mentransfer makna atau informasi melalui reseptor visual, dalam hal ini tentu saja kita membicarakan tentang karya film. Banyak penelitian telah dilakukan terhadap dampak film pada budaya masyarakat, akan tetapi hal ini sangat dipengaruhi oleh bentuk perkembangan industri film itu sendiri. Saat ini, proses penyampaian informasi dalam bentuk karya film sangat dibatasi oleh berbagai lembaga terkait, sebut saja lembaga sensor yang pada akhirnya membuat perubahan makna yang ditangkap oleh penonton karena berbagai bentuk sensor yang diterapkan dalam film tersebut. Hal ini tentu saja membuat sebagian sineas merasa kesulitan untuk menuangkan ide dan gagasan dalam bentuk karya yang dapat diapresiasi oleh publik.

Festival film tidak hanya menampilkan karya film dalam sebuah ruang pertunjukan, lebih jauh, sebuah festival juga secara aktif melibatkan para penonton untuk melakukan interaksi melalui konteks program kegiatan dan nilai-nilai kuratorial yang diberikan oleh para kurator yang menegaskan berbagai logikanya (Haslam, 2004). Bentuk program yang di proyeksikan oleh kurator perlu mencerminkan gagasan mendasar bagi setiap festival film yang dilaksanakannya. Selain itu, gagasan tersebut perlu dipahami dalam setiap pelaku di dalamnya, hal ini yang dapat memberikan pemahaman secara utuh pada setiap penonton yang menghadiri sebuah festival film. 
Penelitian ini dimulai dengan mengidentifikasi pencarian dalam mesin pencari Google yang mencantumkan lebih dari 30 juta referensi untuk istilah festival film; bukti sejauh mana peristiwa-peristiwa ini meresap dalam budaya masyarakat kontemporer. Angka ini adalah detail penting mengingat faktor 'pengalaman' yang memainkan peran penting dalam mengembangkan persepsi dan pada akhirnya memotivasi partisipasi dari para praktisi terkait. Sederhananya, semakin besar kualitas festival film yang 'diketahui' secara umum, semakin kecil pula upaya 'meng-edukasi' dimensi fungsional para calon peserta atau sineas- - sineas yang akan terlibat di dalamnya. Oleh karena itu, peneliti merasa memliki kepentingan untuk mengembangkan wacana praktik kuratorial sebagai bentuk dukungan yang membangun diskursus dalam setiap pelaksanaan festival film.

Liz Czazch mengungkapkan bahwa pemrograman festival film yang sedikit dipahami atau diinterogasi. Seperti yang Patricia Thomson baru-baru ini catat dalam artikel Variety, "Semua orang tahu bahwa penerimaan terhadap film terkenal meningkatkan peluang kesuksesan sebuah film. Tetapi hanya sedikit yang memahami mekanisme proses seleksi." Bagaimana festival film menentukan pilihan mereka dan dampak dari pilihan-pilihan ini adalah fenomena yang kompleks namun tidak tereksplorasi. Ketika festival film di seluruh dunia terus berkembang, pertanyaan tentang bagaimana festival film dan mandat pemrograman berkontribusi pada budaya film global, bagi kehidupan kota-kota festival film, serta keberhasilan film individu dan pembuat film memerlukan pertimbangan serius. Festival film internasional terkenal seperti Cannes, Berlin, Venice, Toronto, dan Sundance memainkan peran besar dalam budaya film nasional dan internasional, membawa perhatian yang terkonsentrasi dari pers, industri, dan publik ke film-film pribumi dan asing. Sementara masing-masing festival ini menyediakan platform untuk memamerkan pilihan internasional mereka, menyoroti pembuatan film pribumi juga umum dalam program-program seperti Perspektive Deutsches Kino di Festival Berlin, American Showcase dan American Spectrum di Sundance atau Perspektif Kanada di TIFF (Czach, 2004).

Selain itu, Felicia Chan dalam penelitiannya "The International Film Festival and the Making of National Cinema”, mengeksplorasi fenomena festival film melalui pembangunan bioskop, proses seleksi film, distribusi dan pameran untuk memberbicarakan kebijakan. Chan juga merujuk kritik De Valck tentang 'dogma penemuan' yang telah memandu sebagian besar festival film sejak 1980-an. Menanggapi pergeseran yang lebih luas dalam industri film, Chan menulis bahwa festival "mulai menyusun kembali apa yang mendefinisikan gaya avant-garde, film eksperimental dan alternatif", serta mempertanyakan bagaimana "hierarki festival film" mempengaruhi pemilihan film dan akibatnya dapat menentukan ketentuan untuk pameran, distribusi potensial dan produksi. Chan membuat bingkai pemikiran "memberi makan ekonomi politik (kebijakan) dari produksi film" (Chan, 2011). Melihat proses penelitian terkait festival film sudah banyak dilakukan, peneliti juga mencoba menyajikan tambahan utama pada literatur tentang topik festival film. Dengan kombinasi bab-bab yang secara khusus meneliti sejarah, teori, metode dan praktik. Struktur yang jelas dan pendekatan sistematis untuk mempelajari festival film. Menawarkan kumpulan esai yang ditulis oleh berbagai sarjana internasional yang mapan, ia membahas festival film terkenal di Eropa, Amerika Utara dan Asia, tetapi sama-sama mencurahkan perhatian pada beragam beragam acara kecil dan/ atau khusus yang berlangsung di seluruh dunia. Ini memberikan pengetahuan 
penting tentang asal-usul dan pengembangan festival film, membahas penggunaan teori untuk mempelajari festival, mengeksplorasi metode penelitian etnografi dan arsip dan melihat secara dekat praktik profesional pemrograman dan pendanaan film (Valck, Kredell, and Loist, 2016).

Dalam penelitian ini, peneliti melakukan eksplorasi pada bentuk budaya baru yang terdapat dalam program festival film, khususnya Festival Film Sineas Mahasiswa 2020 yang diselenggarakan oleh Himpunan Mahasiswa Film dan Televisi (HMFT) FPSD UPI untuk membantu peneliti menangkap gagasan sosial sebagai inspirasi yang menambah wawasan penonton dalam memaknai pesan yang disampaikan oleh program-program dalam festival film tersebut.

Referensi tentang 'kompleksitas' operasi festival film telah dimunculkan berkali-kali. Akar kompleksitas ini berasal dari dasar sistem sosial di mana motivasi untuk interaksi dalam sebuah penyelenggaraan festival film terjadi. Fakta bahwa festival film membutuhkan berbagai sumber daya (dalam hal ini adalah kurator yang memiliki peran sebagai pengkaji wacana), menunjukkan kontribusi terhadap situasi paradoks di mana kepuasan para sineas yang terlibat merupakan dasar keberhasilan sebuah penyelenggaraan festival film.

Dari penelitian terdahulu, peneliti melakukan pemeriksaan mendalam tentang kondisi partisipasi, khususnya dari perspektif kurator. Informasi tersebut, pada dasarnya, 'melengkapi gambar' dari interaksi festival film. Ini akan memungkinkan pemahaman yang lebih besar mengapa penelitian ini efektif dalam menghadirkan skenario interaksi yang lebih menguntungkan dari pada partisipasi tanpa manipulasi seperti pemutaran film biasa. Kompleksitas penyelenggaraan festival film merupakan salah satu bidang studi terpenting di masa depan berkenaan dengan pengembangan pemahaman yang komprehensif tentang perayaan festival film di bawah paradigma kontemporer saat ini. Kita dapat melihat peran korator dalam berpartisipasi akan memungkinkan wawasan yang lebih besar, dan pada akhirnya berkontribusi pada cara yang lebih maju untuk menentukan keberlangsungan sebuah festival film. Namun, studi tersebut membutuhkan pengkajian yang lebih mendalam dan peneliti harus mempertimbangkan bidang ini dengan banyaknya studi kasus yang tepat.

\section{Metode}

Penelitian ini berjenis kualitatif, di mana peneliti melakukan eksplorasi pada wujud peristiwa di lapangan yang di mana penonton menjadi pusat dari dinamika konteks kontemporer dalam festival film. Program yang berlangsung dalam festival film dianalisis oleh peneliti dari sudut pandang identitas dan reputasinya sehingga menjadi bahan analisis yang ditawarkan dalam penelitian ini (Lampel and Meyer, 2008). Sebagian besar data penelitian berbentuk data, data yang terkumpul merupakan hasil pengamatan di lapangan yang dilakukan oleh peneliti. Pada Februari 2020, peneliti bekerja sama dengan Himpunan Mahasiswa Film dan Televisi (HMFT) FPSD UPI melangsungkan kegiatan Festival Film Sineas Mahasiswa (FFSM) 2020. Kegiatan festival film ini merupakan kerja kolaborasi antara HMFT FPSD UPI dengan beberapa Institusi lain di kota Bandung, diantaranya; UNPAD, ISBI, ARS University, UNIKOM, Kampung Film Black Team dan Teras Sineas dari Sanggar Seni Rupa Kontemporer.

Pengumpulan data dilakukan dengan wawancara mendalam, wawancara dengan format pertanyaan terbuka pada kurator yang terlibat dalam FFSM 2020. Observasi langsung 
dan pemanfaatan dokumen dan catatan program juga dilakukan untuk mendapatkan data yang lebih konprehensif.Data wawancara terbuka terdiri dari kutipan langsung dari orang tentang pengalamannya, opini, perasaan, dan pengetahuan. Data hasil observasi terdiri diskripsi mendalam mengenai kegiatan suatu program, perilaku para partisipan, dan interaksi antar praktisi yang terlibat secara luas yang dapat menjadi bagian dari pengalaman program. Dokumen dari kutipan-kutipan yang dianalisis, kutipan-kutipan, atau seluruh kalimat dari hasil rekaman, surat menyurat dan laporan resmi (Welch and Patton, 1992).

\section{Hasil dan Pembahasan}

Peneliti tertarik pada representasi film berdasarkan aspek-aspek di beberapa bidang, termasuk sejarah seni, studi film, studi budaya dan geografi. Para peneliti dalam studi film dan budaya secara kritis melibatkan hubungan antara ruang dan bioskop (tempat pemutaran film), untuk membongkar representasi masyarakat urban pada film yang berkontribusi pada bagaimana kita memahami tempat, makna dan pengaruh letak geografi.

Festival film adalah acara industri budaya yang secara kompleks berkembang pesat dalam beberapa tahun terakhir. Meskipun dicirikan sebagai situs konsumsi yang spektakuler, peneliti berpendapat festival film adalah bentuk kegiatan yang signifikan dalam sistem produksi film. Mempelajari peristiwa festival film sebagai momen yang juga ada kaitannya dengan ekonomi penting dan relevan dengan industri budaya. Ada dua hal penting yang dapat kita amati bersama dari peristiwa festival film: pertama, pekerjaan pada industri budaya cenderung terstruktur melalui campuran tangan perusahaan besar (pemilik modal), lembaga dan proyek yang ditopang oleh pekerja kreatif (dalam hal ini sineas) dalam membangun karier mereka. Kedua, industri budaya,dan dunia seni yang merupakan sistem produksinya, memiliki peristiwa penting (contohnya festival film) sebagai kegiatan bersama untuk melakukan distribusi gagasan dari para sineas yang terlibat di dalmnya.

\section{Festival Film Sebagai Sistem Interaksi Sosial}

Peneliti melihat festival film sebagai sistem sosial dan interaksi yang terjadi berdasarkan berbagai bentuk partisipasi. Partisipasi ini tidak terjadi secara alami tetapi merupakan hasil dari motivasi aktor individu. Dalam hal ini peran kurator menjadi sangat penting sebagai pembentuk wacana dan gagasan besar dari penyelenggaraan festival film. Kurator festival film yang sukses, Darryl MacDonald berkomentar bahwa ia "selalu kagum" ketika ia mendapat "panggilan dari seseorang yang ingin memulai festival film yang berpikir bahwa ada semacam cetak biru yang akan membuat semuanya menjadi sederhana" (Macdonald, 1998). Mereka yang menghadiri festival film hanya melihat sebagian kecil dari kompleksitas organisasi acara tersebut. Jumlah koordinasi, negosiasi, waktu dan upaya yang diperlukan untuk mengoperasikan festival film fungsional seringkali membuat penyelenggara tidak siap. Alan Franey (Tanner, 2009), Direktur Festival Film Internasional Vancouver, menjelaskan bahwa tantangan operasi yang tak terduga sering membuat diskusi yang jujur tentang operasi festival film sebagai "discouraging as it is encouraging". Tantangan ini telah memunculkan semakin banyak kurator festival film yang secara khusus bekerja dengan penyelenggara festival film untuk mengatasi kesulitan pada gagasan pelaksanaan sebuah festival film. Lauri Rose Tanner misalnya, dalam bukunya Creating Film Festivals: 
Everything You Wanted to Know But Didn't Know Who to Ask, menyajikan sejumlah informasi yang mengesankan, tetapi ia tidak memberikan penilaian kritis yang menyatukan. Dalam skala yang jauh lebih besar terdapat, International Film Festival Summit (IFFS) yang misinya memproklamirkan diri adalah untuk "mempromosikan dan memperkuat industri festival film global melalui pendidikan, jaringan, penyebaran informasi dan pengembangan standar tinggi untuk industri". Dilembagakan pada tahun 2002, IFFS menawarkan apa yang disebutnya Program Profesional Festival Film Bersertifikat. Program dua hari ini secara optimis bertujuan untuk memberikan "kurikulum pelatihan mendalam yang mencakup unsurunsur paling penting yang terlibat dalam pekerjaan festival film" (Tanner, 2009).

Dapat dikatakan bahwa konteks ini ada karena kesenjangan yang dirasakan antara apa yang secara praktis diketahui dan apa yang dipahami secara akademis. Yaitu, mereka yang memiliki pengalaman praktis dalam penyelenggaraan festival film memahami bahwa sebenarnya dari acara tersebut perlu adanya interpretasi oleh praktisi berpengalaman dalam hal ini adalah peran seorang kurator.

Festival film adalah media di mana identitas berbasis masyarakat muncul melalui kelompok-kelompok kepentingan (pemangku kepentingan) dengan bentuk, fungsi dan makna yang terkandung di dalamnya; dan di sekitar persimpangan dengan seni, budaya, inovasi dan identitas, kekuatan (Rüling and Strandgaard Pedersen, 2010). Proses pembuatan makna dan penciptaan muncul dari festival film yang menyatukan beragam pengalaman dan serangkaian nilai serta minat yang berbeda. Karena festival film bersaing dengan perubahan konstan sebagai institusi budaya, politik, ekonomi dan sosial dalam konteks fenomena festival film, nilai yang terdapat dalam sebuah festival film berakar pada pengalaman kolektif dan penciptaan nilai-nilai simbolis yang tak berwujud bagi komunitas pemangku kepentingan (Vilhjálmsdóttir, 2011). Festival adalah tempat kekuasaan dan hubungan kekuasaan yang ditandai oleh hubungan, hal ini seringkali tersembunyi di antara banyak pemangku kepentingan; peristiwa merangkum dan membentuk pasar, industri, teknologi, atau pengembangan profesi. Mereka adalah ruang untuk jejaring, pengambilan keputusan, pengambilan kesepakatan, distribusi, dan pertukaran, di antara banyak kemungkinan lainnya; dalam konstruk mereka, mereka bergantung pada mekanisme rumit inklusi dan eksklusi (Rüling and Strandgaard Pedersen, 2010).

Sebagai organisasi sementara atau bahkan permanen, festival film dapat dipahami sebagai 'tempat perjalanan' yang bertindak sebagai tempat perjalanan dan pertukaran global, berkontribusi pada konstruksi sosial nilai dan status, dan menyediakan arena kontes struktur lapangan yang berlaku (Rüling, 2009). Festival film berkontribusi untuk memberikan peserta dengan perasaan agenda yang muncul dalam bidang tertentu, dengan mendefinisikan atau mendefinisikan kembali nilai-nilai. Festival dengan demikian memainkan peran penting dalam pembelajaran peserta lapangan dan proses pengambilan akal kolektif, di mana kelompok-kelompok kepentingan secara interaktif menciptakan realitas sosial, yang menjadi realitas organisasi (Rüling, 2009; Rüling and Strandgaard Pedersen, 2010)

Dinamika festival film terletak pada pengalaman peristiwa dan bagaimana evolusi dan proliferasi (baik dalam konteks historis dan kontemporer) berkontribusi pada norma atau struktur kognitif (Vilhjálmsdóttir, 2011; Rüling \& Strandgaard Pedersen, 2010). Ini dicapai melalui reproduksi, kreasi, dan kontestasi nilai-nilai dan kategori-kategori dalam industri, 
yang menyediakan konteks untuk penelitian tentang evolusi makna kelembagaan, organisasi, dan profesional.

Gagasan dari para kurator pada sebuah festival film sudah sepantasnya dapat mempengaruhi dan membangun makna secara kontekstual (Nichols, 1994). Hubungan antar individu dengan kegiatan festival secara keseluruhan juga perlu mempertimbangkan pengalaman kolektif yang berbeda dari tiap-tiap individu. Hal tersebut yang membuat peran kurator menjadi sangat penting, mengingat festival film yang berpusat pada persepsi penonton yang hadir dengan tujuan menarik perhatian, menghibur, mendidik, memberikan inovasi dan tentu saja memberi informasi yang dapat dipahami dari setiap karya atau program yang ditampilkan. Berdasarkan hal-hal tersebut, peneliti mencoba berangkat dari beberapa penelitian terdahulu terkait penyelenggraan festival film, hal ini merupakan upaya yang dilakukan oleh peneliti untuk membangun persepsi baru yang disesuaikan dengan ruang dan waktu yang menjadi subjek saat ini berdasarkan hasil-hasil capaian dari penelitian serupa yang pernah dilakukan sebelumnya.

Sampai saat ini, peneliti masih bertanya terkait sejauh mana festival film menempati posisi operasional pada skala global. Perspektif yang muncul akan sangat beragam, hal ini mengacu pada kepentingan dan tujuan penyelenggaraan festival film tersebut. Dengan kata lain, tidak ada dokumen yang berisi data empiris yang memetakan peningkatan historis dalam jumlah festival film sejak 1932 yang belum muncul dalam penelitian akademis atau praktis. Penelitian ini juga mengesampingkan masalah tersebut, meskipun upaya awal untuk membuat grafik terkait praktik festival film yang sudah pernah berlangsung. Mengetahui berapa banyak festival film yang beroperasi pada titik waktu tertentu akan menghasilkan informasi penting yang dapat digunakan untuk mengembangkan korelasi antara kondisi festival film saat ini, seperti kemunculan teknologi digital dan demokratisasi pembuatan film berikutnya, dan peningkatan sejumlah acara yang bertujuan mengakomodasi kelompok sineas.

\section{Festival Film Sineas Mahasiswa 2020}

Festival Film Sineas Mahasiswa (FFSM) 2020 merupakan kegiatan yang diinisiasi oleh Himpunan Mahasiswa Film dan Televisi (HMFT) Fakultas Pendidikan Seni dan Desain (FPSD) UPI. Kegiatan ini merupakan event tahunan pertama yang bertujuan memberi warna pada perkembangan film di Indonesia, khususnya di tingkat mahasiswa. Dalam pelaksanaan nya, praktisi yang terlibat tidak hanya berstatus mahasiswa, mahasiswa dalam konteks ini merupakan representasi sineas muda yang masih berproses kreatif dalam pola berkaryanya. Dengan tabungan karya yang mereka miliki, sudah sepantasnya festival hasil kolaborasi ini mendapat apresiasi di kalangan sineas pada umumnya. Dengan adanya event tahunan ini, diharapkan menjadi sebuah ekosistem baru yang dapat digunakan para sineas muda yang terlibat di dalamnya untuk terus berkarya, khususnya di dunia film. 


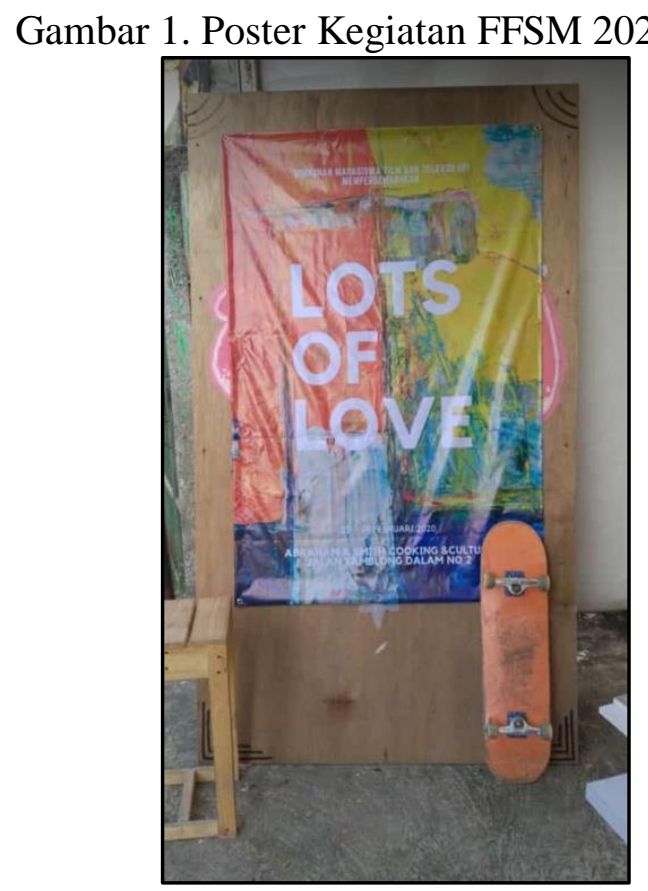

Sumber: Hasil penelitian

Sebagai sebuah kegiatan, Festival Film Sineas Mahasiswa 2020 jelas dibatasi oleh ruang dan waktu atas bentuk pengantar kuratorial yang secara rinci memberikan analisis pada batasan bentuk karya. Hal ini merupakan sebuah daya tarik secara pragmatis yang diberikan oleh kurator sebagai pembentuk wacana dalam festival yang berlangsung. Adapun kurator yang terlibat dalam kegiatan ini adalah (1) Nala Nandana (Peneliti, Kurator Independent, Dosen pengajar di Prodi Film dan Televisi FPSD UPI). (2) Gorivana Ageza (Kritikus Film, Praktisi Bandung Film Commision). (3) Vincent Rumahloine (Seniman Media Rekam) dan (4) Dedi Warsana (Aktor Teater).

\section{Gambar 2. Suasana Kegiatan FFSM 2020}

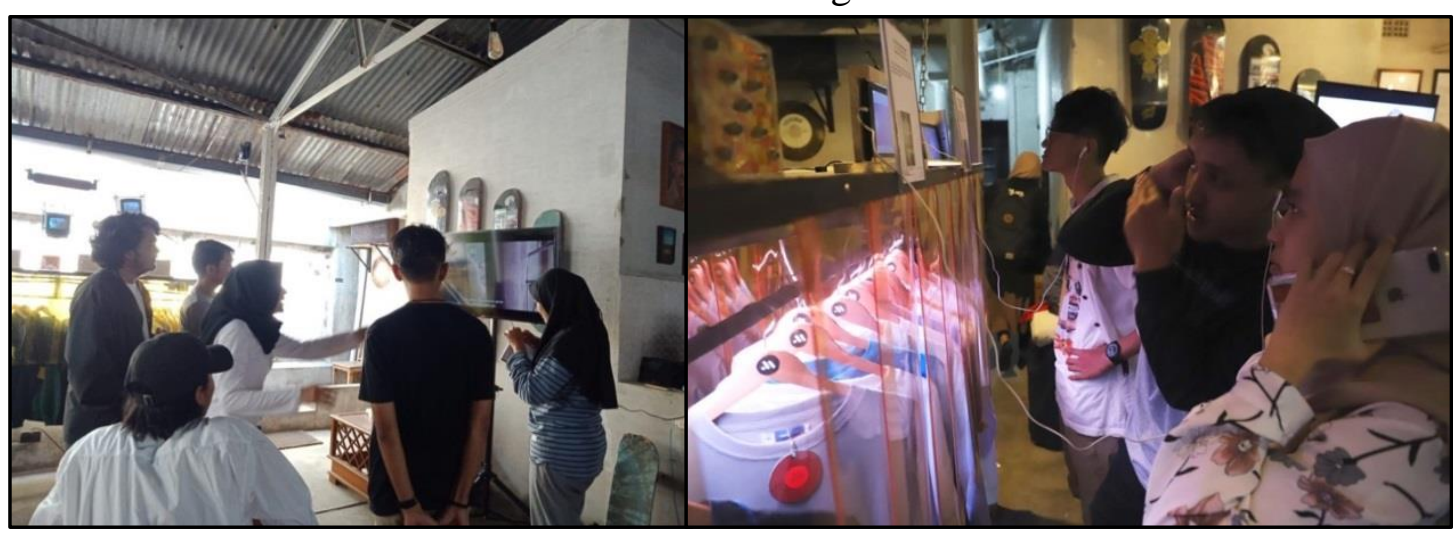

Sumber: Hasil penelitian

Tema yang diangkat pada kegiatan FFSM 2020 adalah Lots of Love, tim kurator mengangkat tema cinta dalam festival yang diselenggarakan kali ini. Film secara universal dapat menjadi salah satu bentuk subjektivitas pembuatnya akan cinta, bukan hanya dari tema 
yang diangkat, gambar yang ditampilkan dan adegan yang diperankan, namun lebih jauh, film merupakan bentuk penyadaran seseorang pada cintanya akan sesuatu (objek). Tidak heran jika tema cinta dapat merajai dunia perfilman saat ini. Fakta tersebut yang membentuk sebuah pemikiran bahwa cinta hanya sebuah perasaan eksklusif yang dirasakan oleh dua orang berlainan jenis.

\section{Peran Kurator Pada Tema Program}

Dari hasil diskusi tim kurator, informan Gorivana Ageza mendefinisikan Lots of Love sebagai sebuah ungkapan sederhana tentang banyaknya cinta di sekitar kita. Cinta merupakan ungkapan universal yang seringkali diungkapkan oleh seseorang dan kemudian dilanjutkan dengan tindakan-tindakan. Setiap orang akan memaknai cinta dari berbagai sudut pandang yang berbeda. Manusia bukan satu-satunya objek yang menjadi sasaran tindakan dari cinta, hal lain seperti pekerjaan, hobi, hewan, lingkungan hingga setiap hal yang ada di alam semesta ini pada dasarnya dapat menjadi objek tindakan cinta.

Ada 15 film yang telah melalui tahapan kurasi oleh para kurator, film yang terkumpul dibagi menjadi 3 (tiga) kategori, yaitu (1) Film dengan tema cinta yang memiliki narasi dan gaya tutur serupa, di dalamnya terdapat gambar kafe, kopi, buku dan kampus. Film film di kategori ini menggambarkan kehidupan sehari-hari kaum muda urban yang seakan belum berwarna jika belum mengalami pergolakan asmara. (2) Film dengan tema relasi personal dalam institusi sosial terkecil, yaitu keluarga. Cerita tentang angan-angan terkait keinginan memiliki keluarga yang utuh, bahagia dan penuh kasih sayang namun berbenturan dengan realitas seperti kemiskinan, tercerai-berai, miskin dan sakit. (3) Film dengan tema jenaka, mengolok-olok imaji ideal mengenai manusia, romansa, cita-cita dan spiritualitas. Cerita yang diangkat mengedepankan kisah hidup sehari-hari namun lebih terasa manusiawi.

Cinta pada harfiahnya merupakan perasaan simpati yang seringkali melibatkan emosi. Dalam pribadi yang sedang mencinta, terdapat empat gejala yang seringkali muncul, diantaranya; care, responsibility, respect, dan knowledge. Gejala tersebut diutarakan oleh informan Vincent Rumahloine yang mengatakan "bohong besar" jika seseorang mengatakan kecintaannya pada alam, namun tidak pernah memberikan perhatiannya pada alam, tidak menunjukan tanggung jawabnya pada alam serta tidak menunjukan rasa hormatnya pada alam. Menemukan objek sebenarnya dari cinta atau dicintai itu sulit, hal tersebut tidak sesederhana yang kebanyakan orang asumsikan. Cinta bukan hanya perasaan sentimental, bukan hanya kemampuan untuk mengasihi sesama namun lebih jauh, cinta merupakan kemampuan untuk mengembangkan diri secara menyeluruh untuk meyakini suatu hal.

Sebagai sebuah hubungan antar sineas yang terlibat di dalamnya, teks kuratorial yang dibangun oleh tim kurator dalam festival film memperkuat berbagai bentuk program yang disajikan pada penonton. Hal ini tentu saja akan menjadi bahasan menarik, terutama saat disajikan pada penonton yang cenderung beragam. Dalam Festival Film Sineas Mahasiswa 2020, sebagin besar penonton yang hadir berharap memperoleh bentuk visual yang sama seperti saat mereka menyaksikan film di bioskop komersial. Namun praktik kerja kuratorial sebagai penyampai informasi massal akan bekerja dalam porsi ini. Teks pengantar dan wacana yang dilontarkan dalam program diskusi publik menjadi poin penting dalam penyelenggaraan sebuah festival film. Hal ini memberikan diskursus yang lebih mendalam 
pada tataran konsep, gagasan dan ide, sehingga pola ini akan menggiring perspektif penontong untuk melihat gagasan dari film yang mereka tonton, dan bukan hanya melihat aspek teknis. Praktik ini merupakan salah satu bentuk pengelolaan informasi yang akan dikonsumsi khalayak luas, dengan kata lain praktik penyampaian komunikasi pada khalayak luas (massa) menjadi tujuan utama yang secara tidak langsung sedang berlangsung. Proses ini merupakan upaya mempengaruhi persepsi penonton untuk tidak hanya melihat sebuah tontonan hanya dari satu kajian teknis, namun lebih jauh, tim kurator dalam kegiatan ini ingin menggiring pemahaman penonton untuk dapat lebih dalam mengapresiasi karya film yang ditampilkan dalam kegiatan festival tersebut.

Bentuk-bentuk budaya keterlibatan penonton dalam sesi diskusi menjadi program utama dalam kegiatan festival ini. Melihat tingkat kesulitan dari penonton untuk memaknai gagasan dan ide dari para sineas yang dituangkan dalam karya film di festival ini. Hal ini cukup lumrah dalam pelaksanaan sebuah festival, maka tidak jarang jika film-film yang ditampilkan dalam sebuah festival akan sedikit sulit jika harus bersaing dengan film komersial. Sehingga sesi tanya jawab, baik dengan tim kurator maupun dengan para sineas menjadi program yang ditunggu-tunggu oleh penonton, hal ini ditunjukan dari banyaknya penonton yang hadir dalam sesi tanya jawab di hari terakhir festival. Aktivitas ini menunjukan bahwa dialog terkait komunikasi dalam bentuk gagasan dalam film dapat menghasilkan diskursus yang menarik, memunculkan pertanyaan baru yang mendorong jawaban-jawaban inovatif bagi perkembangan dunia film, khususnya di kalangan mahasiswa.

Kekhususan segmen mahasiswa dalam festival yang dilaksanakan sangat beralasan, analisis yang diperoleh dari kegiatan ini dapat berfokus pada dialog-dialog yang membangun karya film di masa mendatang. Walaupun kita perlu memahami bahwa objek studi film memerlukan cara menganalisis tersendiri. Penggabungan informasi yang diberikan dalam dialog film tidak dapat hanya mengacu pada pengantar yang diberikan oleh kurator.

\section{Simpulan}

Sebagaimana yang sudah dipaparkan dala pendahuluan, studi ini menjelaskan tentang praktik kerja kuratorial yang dilakukan oleh tim kurator dalam mengomunikasikan informasi dalam bentuk wacana di festival film. Bidang-bidang penting yang membutuhkan perhatian dan fokus dinyatakan dalam penelitian ini adalah pengembangan model yang meresmikan peran kurator dalam sebuah penyelenggaraan festival film. Hingga saat ini, praktik kerja kuratorial dalam festival film masih dalam ranah pemilihan karya-karya yang akan ditampilkan. Adapun wacana yang dibangun hanya bersifat membatasi jenis karya film yang akan masuk ke dalam festival tersebut. Lebih jauh, peneliti merasa perlu adanya sebuah terobosan yang berani untuk membangun sebuah wacana yang nantinya akan menjadi topik utama dalam penyelenggaraan sebuah festival film.

Bidang penelitian tentang fenomena festival film khususnya dari perspektif kerja kuratorial tim kurator festival film memberikan wawasan dan pemahaman tentang sifat multidimensi festival film dan masyarakat kontemporer. Peluang unik untuk terlibat dengan komunitas pemangku kepentingan, dari perspektif lokal tetapi dengan lensa global, memberikan tonggak sejarah dari festival film yang memberikan cara pandang eksploratif 
untuk mengubah pemahaman kita tentang gambar bergerak dan perannya yang kuat dalam rangkaian festival film.

Dalam kacamata komunikasi massa, peran kurator menjadi sangat penting, terutama dalam proses pemilihan tema dan pelaksanaan program. Dalam FFSM 2020, proses komunikasi yang dilakukan oleh tim kurator menunjukan bahwa proses kegiatan serupa perlu dilakukan dikemudian hari. Hal ini sangat berkaitan erat dengan respon yang diberikan oleh para sineas yang terlibat maupun pengunjung yang dating mengikuti program kegiatan dalam FFSM 2020. Sebagai jembatan penyampai informasi pada khalayak luas, peran kurator menjadi sangat penting, terutama jika dilihat dari muatan informasi yang akan disampaikan. Hal ini akan memberikan dampak pada luaran kegiatan yang dilaksanakan, sebut saja pertumbuhan wacana yang membangun ketertarikan pada aktivitas serupa maupun perkembangan minat yang menimbulkan efek ekonomi dan sosial dari aktivitas yang dirancang, dalam hal ini kita meggarisbawahi aktivitas pelaksanaan festival film dengan segala turunannya.

Penelitian ini berkontribusi pada kemunculan dan pengaruh FFSM 2020 sebagai festival film mahasiswa, dan telah melegitimasi kehadirannya dan menumbuhkan atributatribut dari pengalaman pengaturan lapangan yang mungkin akan sulit diperoleh jika para pelajar tersebut masuk ke ranah festival film secara umum. Fokus strategis festival pada audiensnya menyediakan konteks untuk memahami upaya yang dilakukan untuk memastikan keseimbangan pertumbuhan, identitas dan relevansi. Sambil menghormati sejarah festival untuk menciptakan pengalaman festival yang berkesan. Temuan menunjukkan bahwa ada kompleksitas yang terkait dengan FFSM 2020 yang dapat membangun teori atau memfasilitasi berteori baik sebagai praktik reflektif atau sebagai pemecahan masalah yang rasional.

Penelitian ini mencerminkan pengumpulan perspektif dan pendekatan yang dapat berkontribusi tidak hanya untuk pemahaman kita tentang festival film dan keterkaitan mereka dalam hubungan dengan budaya dan masyarakat kita, tetapi juga bagaimana perbedaan yang berarti dapat dibuat tentang bagaimana suatu peristiwa dipahami. Dari kacamata kurator festival, penelitian ini menyoroti bagaimana FFSM 2020 diorganisir, diprogram dan dikuratori untuk mengungkapkan elemen-elemen dari proses untuk menciptakan pengalaman festival yang memuaskan tuntutan para pemangku kepentingan yang bersaing, sambil menegaskan logika kelembagaannya secara dinamis, serta untuk lebih memahami karya film dalam sebuah festival film sebagai fenomena multidimensi.

Kontribusi dari penelitian ini terhadap FFSM 2020 dan relevansinya sebagai sebuah institusi, merupakan bentuk dari upaya menjawab pertanyaan seperti: Apa peran kurator dalam proses mewacanakan dan merancang program serta elemen-elemen yang mempengaruhi pengalaman dalam sebuah festival film? Bagaimana FFSM 2020 memperoleh identitas dan reputasinya? Kontribusi spesifik dan relevansi sosial yang lebih luas dengan tubuh pengetahuan, adalah bahwa FFSM 2020 maju dari perspektif sisi penawaran konseptualisasi festival film secara nasional bahkan internasional. Peran penting yang diletakannya dalam acara festival dan pengalaman yang muncul; dan berbagi perspektif penting yang sangat penting untuk berhasil mempelopori FFSM 2020. 
Penelitian ini juga mengusulkan, mengeksplorasi dan menyoroti kerangka teori yang berguna dalam menempatkan sebuah festival film di tingkat pelajar secara retrospektif dalam membentuk rancangan program-program yang akan diakomodir di dalamnya. Diharapkan bahwa analisis yang disodorkan akan membantu dalam pemahaman kita tentang bagaimana menavigasi wawasan profesional atau ahli untuk menentukan dan menyoroti tanggung jawab yang terkait dengan ruang lingkup dan pengembangan identitas, status dan reputasi.

Dalam FFSM 2020 sepertinya kurang tepat jika kita menilai karya-karya film yang diikutsertakan melalui parameter yang biasa digunakan dalam kebanyakan festival film lainnya. Kita dapat melihat terdapatnya keragaman hal-hal yang sangat berhubungan dengan masalah teknis yang justru membuat festival ini menarik untuk dilihat dan dikaji dari sudut pandang lain. Bagi peneliti hal teknis juga penting dalam hal apapun tetapi kadang kita terlalu berkonsentrasi kepada hal-hal teknis sehingga kita kehilangan kesenangan dan menjadi takut dalam berkarya terutama pada masa di mana sepertinya semua hal sudah dilakukan.

Tim kurator FFSM 2020 melihat satu hal penting dari karya-karya yang ditampilkan yaitu kemampuan dan keberanian para sineas muda ini untuk mengeksekusi ide mereka dengan segala keterbatasannya dan resiko yang mungkin akan mereka hadapi. Hal-hal teknis akan berkembang seiringnya proses belajar dari para sineas muda ini. Tim kurator juga tertarik untuk lebih berbicara atau berdiskusi dengan para sineas muda ini dalam hal ide dan konsep dalam membuat film.

Perlu diketahui para sineas muda ini masih tahap pembelajaran dan eksplorasi sehingga ruang seperti festival film mahasiswa di Indonesia menjadi sangat penting posisinya di perkembangan film, baik dalam lingkup nasional maupun di lingkup internasional. Dalam hal ini peran kurator sebagai mediator kunci penyampaian pesan menjadi tak kalah penting. Peran kurator dapat menjembatani ide sineas yang akan di sampaikan pada audiensnya, dalam konteks ini sisi pengkaji dari praktik kerja kuratorial dapat menjadi bahan bacaan yang menarik, terutama jika dilihat dari sisi penyampaian makna yang terkandung dalam kompilasi film dalam sebuah festival.

Penelitian secara keseluruhan telah menjadi salah satu penelitian yang menyoroti dampak dari hubungan kompleks pada proses pemrograman festival dan pengalaman festival yang muncul dari gagasan kurator. Lebih jauh, peneliti menggarisbawahi pentingnya peran kurator dan sineas secara bersamaan sebagai kolektif untuk keberlangsungan festival film dan dapat mengumpulkan serta memahaminya dengan cara yang cukup unik. Relevansi dampak dari gagasan kurator FFSM 2020 pada program kegiatan dan kekuatan film dalam ranah budaya film global sangat mendalam dan berkembang pada status dan hubungannya yang unik namun hibrid. Namun, tantangan untuk festival ini adalah bagaimana menavigasi dan memanfaatkan modal kolektifnya untuk memperkuat keterlibatan dalam pengertian nonkonvensional dengan pengaruh digital dalam rangka membangun kredibilitasnya untuk menjadi praktisi inovatif yang terus menunjukkan keterlibatan dan pengalaman guna memuaskan imajinasi mata pemirsa. Terbukti dengan berlangsungnya FFSM 2020 dapat mengubah cara pandang para pelajar, khususnya sineas mahasiswa melihat perkembangan film secara global melalui program FFSM 2020. 


\section{Referensi}

Chan, Felicia. (2011). "The International Film Festival and the Making of a National Cinema."

Cherchi Usai, Paolo, David Fransis, Alexander Horwath, and Michael Loebenstein. (2008). No TitleFilm Curatorship: Archives, Museums, and the Digital Marketplace. Vienna: Österreichisches Filmmuseum: SYNEMA--Gesellschaft für Film und Medien; Pordenone, Italy : Le Giornate del Cinema Muto.

Czach, Liz. (2004). "Film Festivals, Programming, and the Building of a National Cinema." The Moving Image 4(1):76-88.

Fischer, Alex, Bcomms Sju, and Mftv Bond. (2009). "Conceptualising Basic Film Festival Operation." Queensland: Bond University, School of Humanities.

Genkova, Lyudmila. (2010). "Racing to the Finals : Programming Principles and Processes in ( Competitive ) Film Festivals The Case with the 40th International Film Festival Rotterdam." University of Amsterdam.

Haslam, Mark. (2004). "Vision, Authority, Context: Cornerstones of Curation and Programming." The Moving Image: The Journal of the Association of Moving Image Archivists 4(1):48-59.

Van Hemert, Tess. (2013). International Acclaim: The Role(S) Of The International Film Festival In Supporting Emerging Women's Cinema. Quensland University of Technology.

Iordanova, Dina. (2009). Film Festival Yearbook 1: The Festival Circuit. St. Andrews, Scotland: St. Andrews Film Studies.

Klippel, Heike. (2008). The Art of Programming. Film, Programm Und Kontext. Hamburg: Lit Verlag Munster.

Lampel, Joseph, and Alan D. Meyer. (2008). "Field-Configuring Events as Structuring Mechanisms: How Conferences, Ceremonies, and Trade Shows Constitute New Technologies, Industries, and Markets." Journal of Management Studies.

Macdonald, Darryl. (1998). How to Launch a Community Fest. In S. Gaydos (Ed.) The Variety Guide to Film Festivals: The Ultimate Insider's Guide to Film Festivals around the World. New York: Berkley Publication. Group.

Manners, Bianca, Melville Saayman, and Martinette Kruger. (2015). "Managing a Live Music Performance: A Supply-Side Analysis." Acta Commercii 15(1).

Nichols, Bill. (1994). "Discovering Form, Inferring Meaning: New Cinemas and the Film Festival Circuit." Film Quarterly University of California Press 47(3):16-30.

Rastegar, Roya. (2012). "Difference, Aesthetics and the Curatorial Crisis of Film Festivals." Screen 53(3):310-17.

Rüling, Charles Clemens. (2009). Festivals As Field Configuring Events: The Annecy International Animated Film Festival And Market. Copenhagen: St. Andrews Film Studies.

Rüling, Charles Clemens, and Jesper Strandgaard Pedersen. 2010. "Film Festival Research from an Organizational Studies Perspective." Scandinavian Journal of Management 26(3):318-23.

Tanner, Lauri Rose. (2009). Creating Film Festivals: Everything You Wanted to Know but Didn't Know Who to Ask. Lauri Rose Tanner (Self Publised).

Valck, De. (2019). "Film Festivals : History and Theory of a European Phenomenon That Became a Global Network." Amsterdam School for Cultural Analysis (ASCA).

Valck, Marijke De, Brendan Kredell, and Skadi Loist. (2016). "Film Festivals: History, Theory, Method, Praxis.” (February). 
Vilhjálmsdóttir, Linda. (2011). "A Documentary Film Festival Circuit and Film Festivals as Field-Configuring Events , Adapting to Digitalization ." Bifröst University.

Welch, Jill K., and Michael Quinn Patton. (1992). "Qualitative Evaluation and Research Methods." The Modern Language Journal 76(4):543. 